\title{
Anti-pancreatic Cancer Potential of Secalonic Acid Derivatives from Endophytic Fungi Isolated from Ocimum basilicum
}

\author{
M. Shoeb ${ }^{1}$, M.E. Hoque ${ }^{1}$, P.K. Thoo-Lin ${ }^{2}$ and N. Nahar ${ }^{1}$ \\ ${ }^{1}$ Department of Chemistry, University of Dhaka, Dhaka-1000, Bangladesh \\ ${ }^{2}$ School of Pharmacy and Life Science, The Robert Gordon University, Aberdeen AB25, 1HG, UK
}

\begin{abstract}
The word endophyte means "in the plant" and refers to all microorganisms that live in the intercellular spaces of stems, petioles, roots and leaves of plants causing no apparent symptoms of disease. Seven endophytic fungi were isolated from the medicinal plant of Ocimum basilicum L. The fungal strain, labeled as $2 \mathrm{~L}$, was cultivated at large scale on the potato dextrose agar semi solid medium and was extracted with ethyl acetate. Normal phase silica gel column chromatography of the ethyl acetate extract afforded ergosterol (1), secalonic acid A (2) and secalonic acid D (3). The structures of these compounds (1-3) were elucidated unequivocally by UV, IR, MS, a series of 1D \& 2D NMR analyses. The cytotoxicity of these compounds was evaluated by the MTT assay against human pancreatic cancer cell line. Secalonic acid A (2) and secalonic acid D (3) exhibited significant anti-pancreatic cancer activity with $\mathrm{IC}_{50}$ values of 7.3 and $1.6 \mu \mathrm{M}$, respectively.
\end{abstract}

Key words: Endophytic fungi, Secalonic acida A and D, Ergosterol, Pancreatic cancer.

\section{INTRODUCTION}

Pancreatic cancer is an aggressive cancer which usually leads to death sentence. It has been estimated that 29,200 new cases are diagnosed a year in the United States and more than 30,000 in Europe..$^{1-2}$ Ductal adenocarcinoma of the pancreas is the fourth causative of death from malignant disease in the world. ${ }^{3}$ Despite the application of new combination of chemotherapy and radiation therapy, prognosis of patients with pancreatic cancer remains very poor. ${ }^{4}$ Gemcitabine is currently the drug of choice for treatment with the response rate of $23.8 \%$ in pancreatic cancer patients. ${ }^{5}$ However, the relatively low response of gemcitabine means that there is still an urgent need for new and more efficient therapies. Endophytic microorganisms are a rich source of bioactive compounds with great potential in contributing to the discovery of new lead structures for future drug development. With the bioactive strains, it is possible to cultivate them in large scale

Correspondence to: $\mathrm{M}$. Shoeb

E-mail: shoeb71@yahoo.com

Dhaka Univ. J. Pharm. Sci. 12(2): 91-95, 2013 (December) by fermentation to yield the active compound(s) in larger amount rather than destroying natural plant resources. Ocimum basilicum Linn (Tulsi) is one of the important medicinal plants of Bangladesh. We, now report the isolation of endophytic fungi from $O$. basilicum and isolation of ergosterol (1), secalonic acid A (2) and secalonic acid D (3) from one fungal strain, and their in-vitro anti-cancer activity against human pancreatic cancer.

\section{MATERIALS AND METHOD}

General. UV and IR spectra were recorded on Shimadzu UV 160A and Shimadzu IR-470 spectrophotometer, respectively. Mass analyses were performed on Thermo Instruments MS system (LTQ XL/ LTQ Orbitrap Discovery). The ${ }^{1} \mathrm{H}$ and ${ }^{13} \mathrm{C}$ NMR spectra were acquired on a Varian $600 \& 100 \mathrm{MHz}$ spectrometer, respectively. Media was prepared under Laminar flow (Thermo Forma, Class 11 A1; Biological safety cabinet). The culture media was sterilized using HIRAYAMA autoclave (Hirayama MFG Corp.). 
Plant collection and sterilization. The medicinal plant, $O$. basilicum locally known as Tulsi was collected from University of Dhaka. Different parts (leaves, stems and roots) of the plant were cut into small pieces. Each plant part was surface sterilized with $70 \%$ ethanol, $3 \%$ sodium hypochlorite and sterile water.

Isolation, culture and extraction of endophytic fungi. The surface sterilized plant materials were inoculated on autoclaved potato dextrose agar media on a sterilized petridish and after 21 days, seven fungal strains were isolated for identification. One fungal strain labeled as $2 \mathrm{~L}$ was cultivated at large scale on semi solid potato dextrose agar medium. After 21 days the fungi were collected in a round bottom flask and the content was freeze-dried. The dried powdered material was extracted with ethyl acetate $(1500 \mathrm{ml} \times 3$ for $24 \mathrm{~h}$, at room temperature). The combined ethylacetate extract was evaporated to dryness (800 mg).

Chemical studies of the ethyl acetate extract. The ethyl acetate extract $(800 \mathrm{mg})$ was fractionated by normal phase silica gel column chromatography using $n$-hexane as column equilibrating solvent. After application of the sample, solvents of increasing polarities from $100 \%$ hexane to dichloromethane (DCM) followed by $5 \% \mathrm{MeOH}$ in DCM and finally $50 \% \mathrm{MeOH}$ with dichloromethane were used for elution. The fraction collected from $100 \%$ DCM gave single spot in TLC and was collected as pure compound 1 (22.8 $\mathrm{mg}$ ) after washing with $n$-hexane. Compounds $2(16.0 \mathrm{mg})$ and $3(14.0 \mathrm{mg})$ were isolated from column the fraction eluted with $5 \%$ $\mathrm{MeOH}$ in DCM by repeated column chromatography.

Compound 1. White colored gum $(22.8 \mathrm{mg})$; UV (in DCM): $\lambda_{\max } 262,274$ and $415 \mathrm{~nm}$; IR (KBr pellet): $v_{\max } 2900,2850,1720,1450$ and $1250 \mathrm{~cm}^{-1}$; ${ }^{1} \mathrm{H}$ NMR (600 MHz, $\mathrm{CDCl}_{3}$, TMS as standard): $\delta$ $5.57(1 \mathrm{H}, \mathrm{d}, J=7.1 \mathrm{~Hz}, \mathrm{H}-6), 5.38$ (1H, m, H-7), 5.20 $(1 \mathrm{H}, \mathrm{m}, \mathrm{H}-22), 5.20(1 \mathrm{H}, \mathrm{m}, \mathrm{H}-23), 3.63(1 \mathrm{H}, \mathrm{br} ., \mathrm{H}-$ 3), 1.03 (3H, d, $J=6.4 \mathrm{~Hz}, \mathrm{H}-21), 0.94$ (3H, s, H-19), $0.92(3 \mathrm{H}, \mathrm{d}, J=6.7 \mathrm{~Hz}, \mathrm{H}-28), 0.84(3 \mathrm{H}, \mathrm{d}, J=7.0$ $\mathrm{Hz}, \mathrm{H}-27), 0.82(3 \mathrm{H}, \mathrm{d}, J=6.9 \mathrm{~Hz}, \mathrm{H}-26), 0.63(3 \mathrm{H}$, s, H-18): ${ }^{13} \mathrm{C}-\mathrm{NMR}\left(100 \mathrm{MHz}, \mathrm{CDCl}_{3}\right): \delta 141.5$ (C-
8), 139.9 (C-5), 135.5 (C-23), 132.1 (C-22), 119.7 (C-6), 116.4 (C-7), 70.6 (C-3), 55.9 (C-17), 54.7 (C14), 46.4 (C-9), 42.9 (C-13), 41.0 (C-4), 40.6 (C-20), 39.2 (C-12), 38.5 (C-1), 37.2 (C-10), 33.3 (C-25), 32.2 (C-2), 28.4 (C-16), 23.2 (C-15), 21.3 (C-11), 20.1 (C-21), 19.8 (C-26), 19.6 (C-27), 17.8 (C-28), 16.5 (C-19), 12.2 (C-18): HR-ESIMS: 397.2345 $[\mathrm{M}+\mathrm{H}]^{+}$.

Compound 2. Yellow solid (16.0 mg); UV (in DCM): $\lambda_{\max } 228,278 \mathrm{~nm}$; IR (KBr pellet): $v_{\max } 1512$, 1457, $1075 \mathrm{~cm}^{-1}$; ${ }^{1} \mathrm{H}$ NMR (DMSO- $d_{6}, 600 \mathrm{MHz}$ ): $\delta$ $11.6(2 \mathrm{H}, \mathrm{s},-\mathrm{OH}-1, \mathrm{OH}-1$ '), $7.45(2 \mathrm{H}, \mathrm{d}, J=8.4 \mathrm{~Hz}$, H-3, H-3'), 6.63 (2H, d, J = 8.4 Hz, H-4, H-4'), 6.02 $(2 \mathrm{H}, \mathrm{d}, J=6.8 \mathrm{~Hz}, \mathrm{OH}-8, \mathrm{OH}-8$ '), 3.81 (2H, quintet, H-5, H-5'), 3.61 (6H, s, H-13, H-13'), 2.66 (2H, m, Ha-7, Ha-7'), 2.44 (2H, m, Hb-7, Hb-7'), $2.31(2 \mathrm{H}$, sextet, H-6, H-6'), 1.03 (6H, d, J = 6.2 Hz, H-11, H$\left.11^{\prime}\right) ;{ }^{13} \mathrm{C}-\mathrm{NMR}\left(\left(\mathrm{DMSO}-\mathrm{d}_{6}, 100 \mathrm{MHz}\right) ; 186.5\right.$ (C9,C-9'), 178.1 (C-8, C-8'), 170.0 (C-12, C-12'), 158.9 (C-1. C-1'), 158.5 (C-4a, C-4a'), 140.2 (C-3, C-3'), 117.3 (C-2, C-2'), 107.5 (C-4, C-4'), 106.3 (C$9^{\mathrm{a}}, \mathrm{C}-9^{\mathrm{a}}$ '), 101.7 (C-8 ${ }^{\mathrm{a}}, \mathrm{C}-8^{\mathrm{a}}$ '), 85.2 (C-10a ${ }^{\mathrm{a}}, \mathrm{C}-10 \mathrm{a}$ '), 75.2 (C-5, C-5'), 52.8 (C-13, C-13'), 35.8 (C-7, C7'), 29.9 (C-6, C-6'), 17.8 (C-11, C-11'); HRESIMS: $639.1704[\mathrm{M}+\mathrm{H}]^{+}$.

Compound 3. Pale yellow colored solid (14.0 $\mathrm{mg}$ ); UV, IR, NMR and Mass: almost identical those of compound 2.

Cell culture. Human pancreatic adenocarcinoma cell line BxPC-3 (ATCC) were cultured in RPMI 1640 medium (with $25 \mathrm{mM}$ HEPES) (Gibco) supplemented with $10 \%(\mathrm{v} / \mathrm{v})$ foetal calf serum (Biosera, UK) and 1\% streptomycin $(100 \mu \mathrm{g} / \mathrm{ml}) /$ penicillin (100 U/ml) (Gibco, UK). Cells were incubated at $37^{\circ} \mathrm{C}$ in a humidified atmosphere containing $5 \% \mathrm{CO}_{2}$ in an incubator HERAcell $150 \mathrm{i}$ (Thermo Scientific) and the cells were grown in 25 or $75 \mathrm{~cm}^{2}$ flasks. Medium was changed every two days and when flask was at confluence, cells were split in another flask.

Cytotoxic activity. BxPC-3 $\left(1 \times 10^{4}\right.$ cells/100 $\mu 1)$ cells were seeded in 96 well plates. After 24 hours, the compounds (1-3) (100 $\mu 1 /$ well; 24-72 hrs) were added to each well to give a final concentration 
of $1.0-40.0 \mu \mathrm{M}$. After 72 hours of incubation, the cell culture medium was removed and $100 \mu \mathrm{L}$ of sterile-filtered $\quad(0.22 \quad \mu \mathrm{M} \quad$ filter $) \quad 3-(4,5-$ Dimethylthiazol-2-yl)-2,5-diphenyltetrazolium bromide (MTT) solution $(1 \mathrm{mg} / \mathrm{ml}$ in serum free medium) was added to each well. The plates were incubated for 4 hours, at $37{ }^{\circ} \mathrm{C}$. The MTT solution was carefully removed and DMSO $(200 \mu \mathrm{l})$ was added to each well. The addition of DMSO allows the dissolution of the metabolized MTT product. The plates were shaken for 20 minutes, at room temperature and the absorbance results quantified by measuring at $560 \mathrm{~nm}$ on a 96 well plate reader (Epoch BioTech, UK and its software Gen5, Version $1.09){ }^{6}$

\section{RESULTS AND DISCUSSION}

A total of three compounds (1-3) were isolated from the fungal strain $2 \mathrm{~L}$ isolated from $O$. basilicum. The HR-ESIMS spectrum of 1 revealed the pseudomolecular ion $[\mathrm{M}+\mathrm{H}]^{+}$peak at $\mathrm{m} / \mathrm{z}$ 397.2345, suggesting the molecular formula as $\mathrm{C}_{28} \mathrm{H}_{44} \mathrm{O}$. The ${ }^{1} \mathrm{H}$ NMR of compound 1 gave signals at $\delta 5.57(1 \mathrm{H}, \mathrm{d}, J$ $=7.1 \mathrm{~Hz}), 5.38(1 \mathrm{H}, \mathrm{m}), 5.20(1 \mathrm{H}, \mathrm{m}), 5.20(1 \mathrm{H}, \mathrm{m})$ for olefinic protons and resonances at $\delta 1.03(3 \mathrm{H}, \mathrm{d}, J$ $=6.4 \mathrm{~Hz}), 0.94(3 \mathrm{H}, \mathrm{s}), 0.92(3 \mathrm{H}, \mathrm{d}, J=6.7 \mathrm{~Hz}), 0.84$ $(3 \mathrm{H}, \mathrm{d}, J=7.0 \mathrm{~Hz}), 0.82(3 \mathrm{H}, \mathrm{d}, J=6.9 \mathrm{~Hz}), 0.63$ $(3 \mathrm{H}, \mathrm{s})$ for five methyl groups. The ${ }^{13} \mathrm{C}$ NMR spectrum confirmed the presence of 28 carbons, including four quaternary carbons $\left(\delta_{\mathrm{c}} 141.5,139.9\right.$, $42.9,37.2)$, seven methylene $\left(\delta_{\mathrm{c}} 40.6,39.2,38.5\right.$, $32.2,28.4,23.2,21.3)$, eleven methine $\left(\delta_{\mathrm{c}} 135.5\right.$, 132.1, 119.7, 116.4, 70.6, 55.9, 54.7, 46.4, 42.9, 40.6, $33.3)$ and six methyl groups $\left(\delta_{\mathrm{c}} 21.3,19.8,19.6,17.8\right.$, $16.5,12.2)$ in compound $\mathbf{1}$. These spectral data of $\mathbf{1}$ were found to be identical to those reported for ergosterol. $^{7}$ Thus, it was identified as ergosterol (1).

The ${ }^{1} \mathrm{H}$ NMR spectrum of compound 2 displayed signals at $\delta 11.61$ due to the H-bonding between carbonyl-oxygen and hydroxyl proton of the aromatic system. Two doublets at $\delta 7.45(J=8.2 \mathrm{~Hz})$ and 6.63 $(J=8.2 \mathrm{~Hz})$ indicated two aromatic protons in ortho position. The signals at $\delta 3.81 \& 2.31,2.66 \& 2.44$, 1.03 and 3.61 were accounted for two methines, methylene, $\mathrm{CH}_{3}$ and $\mathrm{OCH}_{3}$ groups, respectively. On the other hand, the ${ }^{13} \mathrm{C}$ NMR and DEPT spectra indicated the presence of 16 carbons, including two carbonyl ( $\delta 186.5$ and 170.0), six aromatic $(\delta 158.8$, $117.3,140.2,107.6,158.5,106.2)$, two unsaturated carbons $(\delta 178.1,101.7)$, one quaternary $(\delta 85.2)$, two methines $(\delta 75.2,29.9)$, a methylene $(\delta 35.8)$, a methyl $(\delta 17.8)$ and a methoxy $(\delta 52.8)$ carbons. All protonated carbons were assigned with the help of ${ }^{1} \mathrm{H}-{ }^{13} \mathrm{C}$ HSQC experiment. The ${ }^{1} \mathrm{H}-{ }^{1} \mathrm{H}$ COSY spectrum showed strong correlations between $\mathrm{H}-3$ ( $\delta$ $7.45) \& \mathrm{H}-4(\delta 6.63), \mathrm{H}-7(\delta 2.66) \& \mathrm{H}-6(\delta 2.31)$. The long range $\mathrm{HMBC}$ correlations between $\delta_{\mathrm{H}} \mathrm{H}-3$ (7.45) and $\delta_{\mathrm{c}} \mathrm{C}-1$ (158.9), C-2 (117.3); $\delta_{\mathrm{H}} \mathrm{H}-4$ (6.63) and C-9 (186.5), C-1 (158.9), C-2 (117.3), C-9a (106.3); H-5 (3.81) and C-12 (170.0), C-10a (85.2), C-13 (52.8), C-7 (35.8), C-6 (29.9), C-11 (17.8). The relative configura-tion of $\mathbf{2}$ was confirmed by ROESY studies which indicated that signal at $\mathrm{H}-11$ ( $\delta 1.03, \mathrm{CH}_{3^{-}}$group) had strong correlation with $\mathrm{H}$ $5 / \mathrm{H}-5$ ' $(\delta$ 3.81) and Ha-7/Ha-7' $(\delta$ 2.66). The HRESIMS provided a pseudo-molecular ion $[\mathrm{M}+\mathrm{H}]^{+}$ peak at 639.1704 (required 639.1708) that accounted for the molecular formula of $\mathrm{C}_{32} \mathrm{H}_{31} \mathrm{O}_{14}$. The HRESIMS and NMR data confirmed that 2 was a symmetrical dimer. All spectroscopic data were compared with the reported data of secalonic acid D and found to be identical. ${ }^{8}$ The structure of secalonic acid D was further confirmed by 1D TOCSY studies.

The HR-ESIMS of compound $\mathbf{3}$ also gave $[\mathrm{M}+\mathrm{H}]^{+}$at $\mathrm{m} / \mathrm{z} \quad 639.1706$ (required 639.1708) accounted for the molecular formula of $\mathrm{C}_{32} \mathrm{H}_{31} \mathrm{O}_{14}$. The ${ }^{1} \mathrm{H} \&{ }^{13} \mathrm{CNMR}$, COSY, HSQC, HMBC data were similar to secalonic acid D. However, no correlations were observed between H-11 $(\delta 1.03$, $\mathrm{CH}_{3^{-}}$group) and $\mathrm{H}-5 / \mathrm{H}-5$ ' ( $\delta$ 3.81) in the ROESY experiment indicated $\mathbf{3}$ is an enantiomer of secalonic acid D. From the 1D and 2D NMR spectral data and comparison with the reported values, the identity of compound $\mathbf{3}$ was confirmed as secalonic acid A. ${ }^{9}$

The anticancer activity of the isolated compounds was also evaluated. Human pancreatic cells (BxPC-3) were treated with to ergosterol (1), secalonic acid A (2) and secalonic acid D (3), and 
gemcitabine. Gemcitabine was used as positive control since it is the current drug of choice to clinically treat pancreatic cancer. The anti proliferative effects were evaluated with final concentrations ranging from 0.5 to $40 \mu \mathrm{M}$ after 72 hrs drug exposure, resulting in a dose-dependent inhibition of cell growth, quantified by MTT assay (Fig. 1).
Both secalonic acids revealed very good cytotoxicity with $\mathrm{IC}_{50}$ values of 1.6 and $7.3 \mu \mathrm{M}$ for secalonic acid D and secalonic acid A, respectively. However, the positive control gemcitabine and the third compound ergosterol, isolated from $O$. basilicum only demonstrated cytostatic properties and therefore corresponding $\mathrm{IC}_{50}$ could not be determined (Table 1).

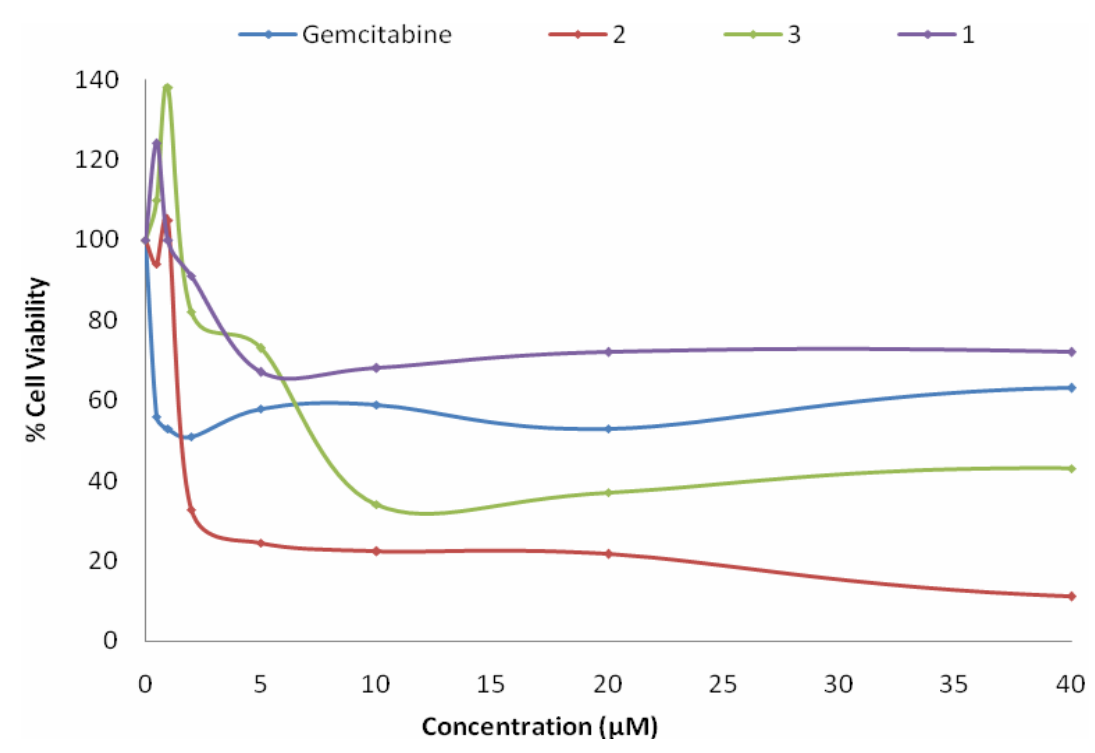

Figure 1. The growth inhibition curve of 1-3 in BxPC-3cells after 72 hrs. Cytotoxicity was determined by MTT assay.<smiles>CC(C)[C@H](C)/C=C/[C@H](C)[C@H]1CC[C@H]2[C@@H]3CC=C4C[C@@H](O)CC[C@]4(C)[C@H]3CC[C@@]21C</smiles><smiles>COC(=O)[C@@]12Oc3ccc(-c4ccc5c(c4O)C(=O)C4=C(O)C[C@@H](C)[C@@H](O)[C@]4(C(=O)OC)O5)c(O)c3C(=O)C1=C(O)C[C@@H](C)[C@H]2O</smiles><smiles></smiles>

Figure 2. Structure of compounds $\mathbf{1}-\mathbf{3}$. 
Table 1. Cytotoxic assay of compounds 1-3.

\begin{tabular}{lc}
\hline Compound & $\mathrm{IC}_{50}$ value $(\mu \mathrm{M})$ \\
\hline Gemcitabine & $\mathrm{NA}^{\mathrm{a}}$ \\
Secalonic acid D (3) & 1.6 \\
Secalonic acid A (2) & 7.3 \\
Ergosterol (1) & $\mathrm{NA}^{\mathrm{a}}$ \\
\hline
\end{tabular}

NA: Not Applicable $-\mathrm{IC}_{50}$ values cannot be determined from data.

Although, ergosterol and secalonic acid derivatives were isolated earlier we report here the successful isolation and characterization of secalonic acid derivatives and ergosterol from endophyte of $O$. basilicum as well as the first in vitro studies of these compounds on pancreatic cancer cell lines. ${ }^{3-5}$ Our studies revealed that secalonic acid derivatives ( 2 and 3) exhibited potent cytotoxic properties and therefore these may be considered as promising candidates for future development in the search for more effective treatment for pancreatic cancer.

\section{CONCLUSION}

The medicinal plant, Ocimum basilicum L. is a good source of endophytic fungi which, in turn, permits the biosynthesis of biologically active molecules.

\section{ACKNOWLEDGEMENTS}

The authors are grateful to International Foundation for Sciences (IFS), Sweden, Organization for the Prohibition for Chemical Weapons (OPCW), The Netherlands. MS thanks Professor Marcel Jaspars and Dr Rainer Ebel, Department of Chemistry, University Of Aberdeen, UK for NMR and Mass facilities and the EPSRC National Mass Spectrometry Service Centre at Swansea University, Swansea for high resolution mass spectral analysis.

\section{REFERENCES}

1. Bramhall, S. R., Allum, W.H., Jones, A. G., Allwood, A., Cummins, C. and Neoptolemos J. P. 1995. Treatment and survival in 13,560 patients with pancreatic cancer, and incidence of the disease, in the West Midlands: an epidemiological study. Br. J. Surg. 82, 111-115.

2. Parkin, D.M., Pisani, P. and Ferlay, J. 1999. Estimates of the worldwide incidence of 25 major cancers in 1990. Int. J. Cancer 80, 827-84.

3. Lowenfels, A.B. and Maisonneuve, P. 2004. Epidemiology and prevention of pancreatic cancer. Jpn. J. Clin. Oncol. 34, 238-244.

4. Lockhart, A.C., Rothenberg, M.L. and Berlin, J.D. 2005. Treatment for pancreatic cancer: current therapy and continued progress. Gastroenterology 128, 1642-54.

5. Novarino, I., Chiappin, G.F., Bertelli, A., Heouaine, G., Ritorto, A., Addeo, G., Bellone, M., Merlano, O. and Bertetto, O. 2004. Phase II study of cisplatin, gemcitabine and 5-fluorouracil in advanced pancreatic cancer. Annals of Oncology 15, 474-477.

6. Barron, G.A., Bermano, G., Gordon, A., Thoo and Lin, P.K. 2010. Synthesis, cytotoxicity and DNA- binding of novel bisnaphthalimidopropyl derivatives in breast cancer MDAMB-231 cells. European J. Med. Chem. 45, 1430-1437.

7. Kwon, H.C., Zee, S.D., Cho, S.Y., Choi, S.U. and Lee, K.R. 2002 Cytotoxic ergosterols from Paecilomyces sp. J300. Arch. Pharm. Res. 25, 851-855.

8. Hong, R., Tian, L., Qianqun, G. and Zhu, W. 2006. Secalonic acid D, a cytotoxic constituent from marine lichen derived fungus Gliocladium sp.T31. Archives of Pharm. Res. 29, 59-63.

9. Steffens, J.C. and Robeson, D.J. 1987. Secalonic acid A, A vivotoxin in pink root-infected onion. Phytochemistry 26, 1599-1602. 